\title{
太陽入射光と介在物の異なる 透過光障子面の光現象が与える質的イメージとその構造 \\ THE STRUCTURE OF QUALITATIVE IMAGES PRODUCED BY LIGHT PHENOMENA ON A SHOJI SCREEN TRANSMITTING DIFFERENT SUNLIGHTS AND OBJECT-SHADES
}

\author{
小泉 隆*，鈴木信 宏** \\ Takashi KOIZUMI and Nobuhiro SUZUKI
}

\begin{abstract}
We have examined qualitative images on a shoji screen which transmitted different sunlights and object-shades. The method we used was to set up a $1 / 3$ scale shoji screen model before several sunlights and objects and observe images of light phenomena. The sunlights were direct setting sun, sky light, 5 all together. The objects which we placed between the sun and the screen were a tree, a pond, a louver, 5 all together. Then we asked architectural students to evaluate each slide picture.

Results : 1. We have obtained the following 9 factors for the qualitative images of a light transmitting shoji screen : I. dynamic $\Leftrightarrow$ still, II. warm $\Leftrightarrow$ cold, III. soft $\Leftrightarrow$ hard, IV. transparent, V. bright $\Leftrightarrow$ cloudy. We could arrange relations of evaluative images such as serenity and pleasantness with these qualitative images from the responses of subjects. 2. We also have obtained causal relations between the conbination of each sunlight with object-shade and these images. 3 . We also have obtained causal relations between light phenomena, including average luminance, luminance pattern, or shade, and these images of the shoji screen.
\end{abstract}

Keywords : light transmitting shoji screen, entering sunlight, light phenomena, qualitative image, experiment for evaluation

透過光障子面, 太陽入射光, 光現象, 質的イメージ, 評価実験

\section{1 . 序および研究の位置づけ}

開口部に用いられ，光を透過した障子やスリガラスなどの素材 (「透過光面」) と呼ぶ）が与える，柔らかさ，冷たさといった質的な イメージは空間の印象を大きく左右する。その為, どんな透過光面 がどんな質的なイメージを与えるかの傾向及びそれらイメージの要 因を捉えておくことは，設計の基礎資料として有用である。

透過光面が与えるイメージを扱った研究には，北浦の「格子とす

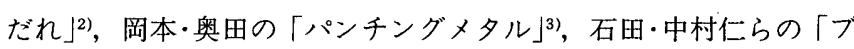
ラインド」4など，1種又は数種の素材を扱ったものがある。しかし そこでは透過光面の向こうへの見え具合や透視性, 快適性などの評 価に関するイメージを主に扱っており，質的なイメージを中心に 扱ったものではない。小泉・山田・鈴木の前稿 1 5では, ガラスブロッ ク，スリガラス，障子，パンチングメタルといった15種類の多様な 素材の透過光面が与える質的なイメージを, 賏天光を想定した蛍光 灯の光を用いた実物大模型評価実験より探った。

しかしながら透過光面が与える質的なイメージは, 素材種類以外 に, 值射光, 䛒天光, 夕日といった入射光の種類や, 開口部の外側 にある樹木や格子といった太陽光と透過光面の間にある介在物の種 類によっても異なってくるが，それらの影響を重視して透過光面の
質的なイメージを扱った研究はない。

本研究は, 素材種類を外部の光の変化を映し出しやすい障子に限 定し， 入射光と介在物の違いによって異なる透過光障子面の輝度の 高さ, 輝度の分布, 影のでき方といった光現象がどんな質的なイメー ジを与えるかを捉えようとしたものである。

そして，設計の基礎資料に役立てたいというねらいより，透過光 障子面が与える質的なイメージの全体的な傾向を捉えつつ, かつ具 体的なイメージの傾向も整理しておくこと，またイメージの要因に 関しても，具体的なイメージの要因を全体的な傾向を踏ま之整理し ておくことが大切と考えた。

障子を扱った小泉・藤井・鈴木の前稿 $2^{6)}$ では，透過光障子面が与 えるイメージの中でも，落ち着きおよび落ち着きの要因となる質的 なイメージを中心に捉えたものである。

しかし透過光障子面が与えるイメージは落ち着きに関連するイ メージ以外にも色々とあり，それらは入射光や介在物の種類が要因 になることが多い。そこで本研究では落ち着きに関連するイメージ 以外にも幅を広げ，透過光障子面が与える幅広い質的なイメージと その要因を捉えようとしたものである。
* 九州産業大学工学部建築学科 講師・博士 (工学)

** 東京理科大学工学部建築学科教授・博士 (工学)
Lecturer, Dept. of Architecture, Faculty of Eng., Kyushu Sangyo Univ., Dr. Eng. Prof., Dept. of Architecture, Faculty of Eng., Science Univ. of Tokyo, Dr. Eng. 


\section{2. 研究の目的}

入射光と介在物が異なる透過光障子面模型のスライド写真による 評価実験より，透過光障子面の光現象が与える質的なイメージとそ の構造を次の 3 点で整理することを目的とした。

(1) イメージ内容の整理

透過光障子面が与える，柔らかい，冷たいといった質的なイメー ジは,どのような因子に代表させることができるかを整理すること。 そしてそれら質的イメージが, 落ち着く, 快適, 魅力的といったど んな評価イメージと結びついているかを整理すること7)。

(2) イメージ傾向の整理

どんな入射光と介在物の組み合わせによる透過光障子面が, どの イメージをよく与えるか，またよく与えるイメージの差異によって 透過光障子面はどの上うに大別できるかを捉之，透過光が与之るイ メージの傾向を整理すること。

(3) イメージを与える要因の整理

透過光障子面の質的イメージを与える要因を, 数量化 I 類分析よ $\eta$, 透過光障子面の輝度の高さ, 輝度の分布, 影のでき方などの光 現象にもとめ整理すること。

\section{3. 評価突験}

\section{1 宊験で扱った透過光障子面（表 1）}

入射光は, イメージが異なるであろう光の質, 色, 強さに着目し, それらにばらつきが出るように 5 種類の光を選定した：(1)夕日直射 光, (2)夕日天空光, (3)直射光, (4)天空光, (5)薄明時の天空光。

介在物は, 出来るだけ一般的で模型制作の容易さを考虑しながら, イメージが異なるであろう 5 種類を選定した：(1)高木，(2)低木，(3) 水面, (4)格子, (5)庇。

また内部の室内光の有無によってもイメージが異なると考え, 室 内光も，透過光障子面の要素として加えることにした。

そしてそれら入射光, 介在物, 室内光の 3 項目の組み合わせより,

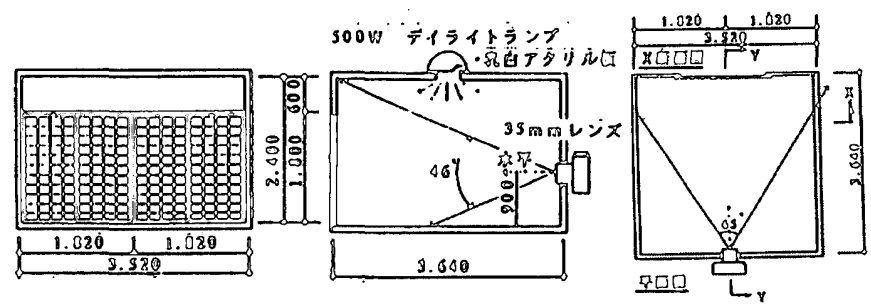

イメージが異なるであろう14種類の透過光障子面を選定し，評価実

験を行うことにした。

\section{2 模型および㴔験用スライド写真の作成（図 1，図 4)}

8 畳間を想定し, 障子は水越障子（組子：縦栈 3 本, 横栈 11 本, 紙：混妙レーヨン・白色）で大きさは $1800 \mathrm{~mm} \times 910 \mathrm{~mm}$ の 4 枚建て とした，縮尺 $1 / 3 の$ 模型を作成した ${ }^{8)}$ 。内装はなるべく光を反射せず また没個性的な物として，木目の目立たないべニヤを素地のまま用 いた。そして実際の天空光, 直射光, 夕陽等を背景に, 障子面模型 外側に樹木や格子などの介在物を配しながら掫影を行った99。室内 側を照らすデイライト（フォト・リフレクタランプ・デイライト 100 $\mathrm{V}, 500 \mathrm{~W})$ は室内光のある 2 例のみに使い，その他は障子外側から の太陽光のみである。レンズは人間の静視野に近い焦点距離 $35 ミ$ を用い(10), 平座位に扔ける目線の高さ $900 \mathrm{~mm}$ の所から水平方向に向 け撮影した。

スライド映写時の障子面部分の平均輝度を測定したところ，14の 透過光障子面の平均輝度範囲は $16 \sim 71 \mathrm{~cd} / \mathrm{m}^{2}$ であった ${ }^{11)}$ (表 1 )。

\section{3 察験で扱ったイメージ形容詞（表 2)}

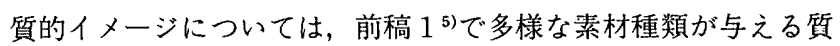
的イメージを代表するとした 8 因子のうち, 素材自体の性質を表し ていた『一様滑らか』, 『粗さ』, 『厚さ重さ』, 『薄さ軽さ』の因子を 構成していた質的イメージを省き，それ以外の『輝き透明』，『濁り 不透明』, 『柔らかさ暖かさ』, 『硬さ冷たさ』の因子を構成していた 13のイメージを扱うことにした。

評価イメージについては, 前稿 $1^{5)}$ と同様に, その意味内容によっ て上位と下位があると仮定して2つに分けて扱うことにした。そし

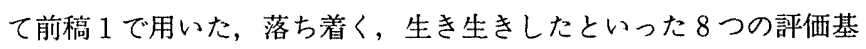
準イメージと, 快適, 魅力的といった $5 つ$ 上位評価イメージを扱 うことにした。

尚, 上記合計26のイメージ形容詞は, mono-polar な尺度として扱 うことにした。

\section{4 評価实験の实施}

14の模型スライドを被験者に見せ，(1)13の質的イメージ，(2) 80 の評価基準イメージ，(3) 5 つの上位評価イメージに対し，それぞれ の感じる度合いを，まったくない〜非常にあるの 7 段階（0６） で封ねた (99年 5 月)。実験室は東京理科大学工学部建築学科第一製 図窒。被験者は建築学科の学部生・大学院生で22人(男：16人, 女： 6人）である。

图 1 透過光障子面模型の立・断・平面図

表 1 実験で扱った透過光障子面

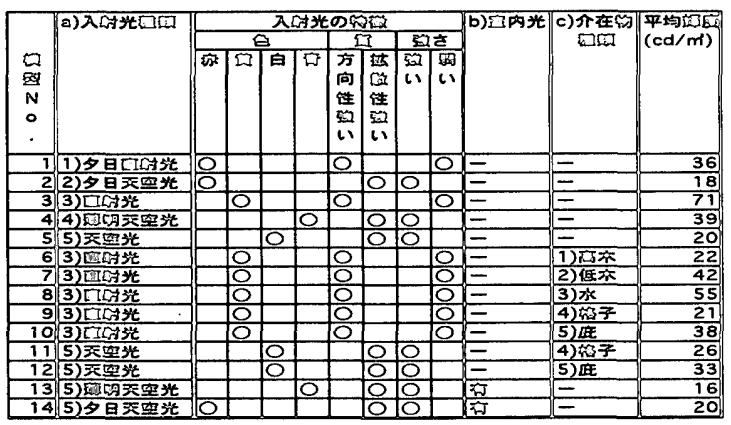

表 2 実験で扱ったイメージ形容詞

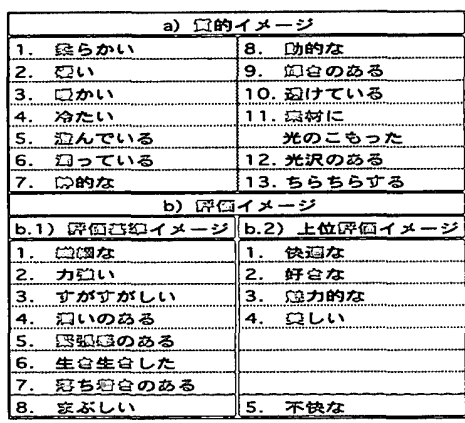

表 3 評価基準イメージと上位評価イメージ との相関

\begin{tabular}{|c|c|c|c|c|c|}
\hline 誁仍基䡛イメージ & \multicolumn{4}{|c|}{ 上位語饮イメーシ } & \\
\hline & 蚮䢔な & 造力的 & 好きな & 美しい & 不快な \\
\hline 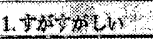 & 0.72 & 0.58 & 0.58 & 0.52 & 0.05 \\
\hline 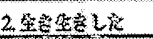 & 0.7 & 0.62 & 0.58 & 0.53 & 0.64 \\
\hline 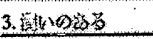 & 0.75 & 0.69 & 0.69 & 0.69 & 0.72 \\
\hline 4.落ち和きのある & 0.37 & 0.53 & 0.59 & 0.61 & 0.50 \\
\hline 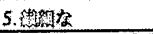 & 0.35 & 0.48 & 0.48 & 0.58 & -0.51 \\
\hline 6. 器張感のある & -0.55 & -0.53 & -0.50 & -0.48 & 0.42 \\
\hline 7. 力強い & 0.29 & 0.21 & 0.11 & 0.13 & .0 .24 \\
\hline 8. まふしい & 0.01 & -0.15 & -0.25 & -0.27 & 0.13 \\
\hline
\end{tabular}


4.イメージ内容の整理

\section{1 質的イメージを代表する 9 つの因子}

アンケート結果より全被験者の平均值を用いて ${ }^{12)}, 13 の$ 質的イ メージの因子分析を行った。その際，軸の数が少ない場合に因子得 点によって14障子面をプロットしてみると入射光や介在物の違いに よる影響がよく捉えられなかった。そこで，因子の数をふやしなが ら因子分析を行い，その都度因子得点による14障子面のプロット図 を作成する作業をくりかえした。そして入射光や介在物がイメージ に与える影響をよく捉えられるものとして，5軸による因子分析結 果を採用することにした。表 4-1）2）3）にその因子の構成を 示す。そして因子の要素となる質的イメージの意味内容の類似性に よって，9つのイメージ因子を次のように命名した ${ }^{14)}($ 表 4-3))

I 軸：『動的』因子 $\Leftrightarrow$ 『静的』因子，II軸：『暖かさ』因子 $\Leftrightarrow$ 『冷たさ』

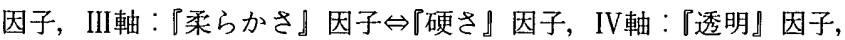
$\mathrm{V}$ 軸：『輝き』因子 $\Leftrightarrow$ 『濁り』因子。

\section{2 質的イメージと評価イメージとの結び付き}

質的イメージと評価イメージとの結びつきを捉えるため，9つの 因子の因子得点と評価イメージ（評価基準イメージと上位評価イ メージ)との相関分析, 質的イメージと評価イメージとの相関分析, そして上位評価イメージと評価基準イメージとの相関分析（表 3) を行った。そして，全体的な傾向を示す因子得点と評価イメージと の相関分析結果（表 4-4）左欄）と，具体的な傾向を示す 13 尺度 の評定值と評価イメージとの相関分析結果（表 4-4）右欄）を同 時に整理した（表 4)。

（1）上位評価イメージと評洒基準イメージとのつながり

表 3 より，すがすがしい，生き生きした，潤いのあるが快適，魅

表 4 質的イメージ因子とその姴素となる質的イメージ及びそれらと評価イメージとの相関

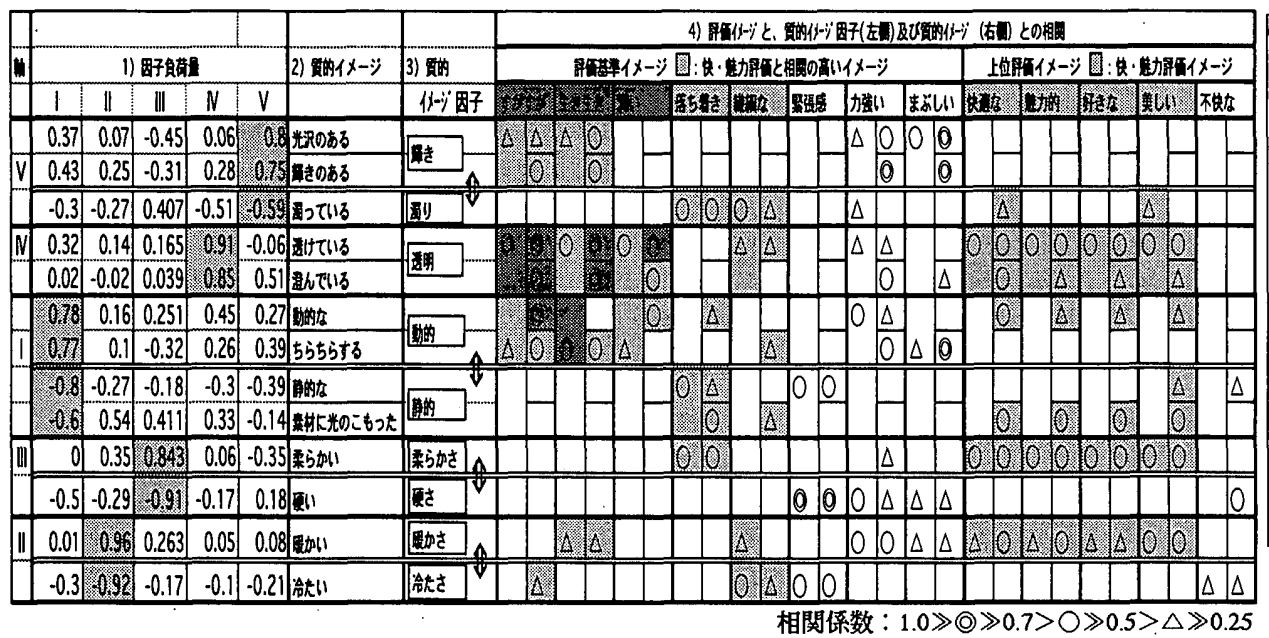

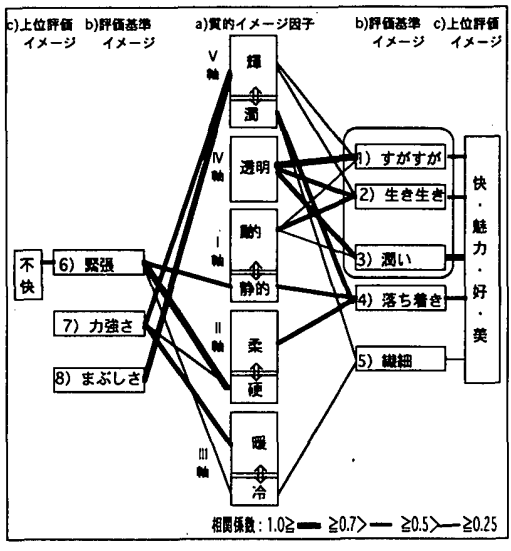

図 2 質的イメージと評価イメージの 結びつきを示す模式図

表 5 イメージ傾向把握の基礎資料：質的イメージ因子の因子得点と質的イメージ，評価イメージの評価得点

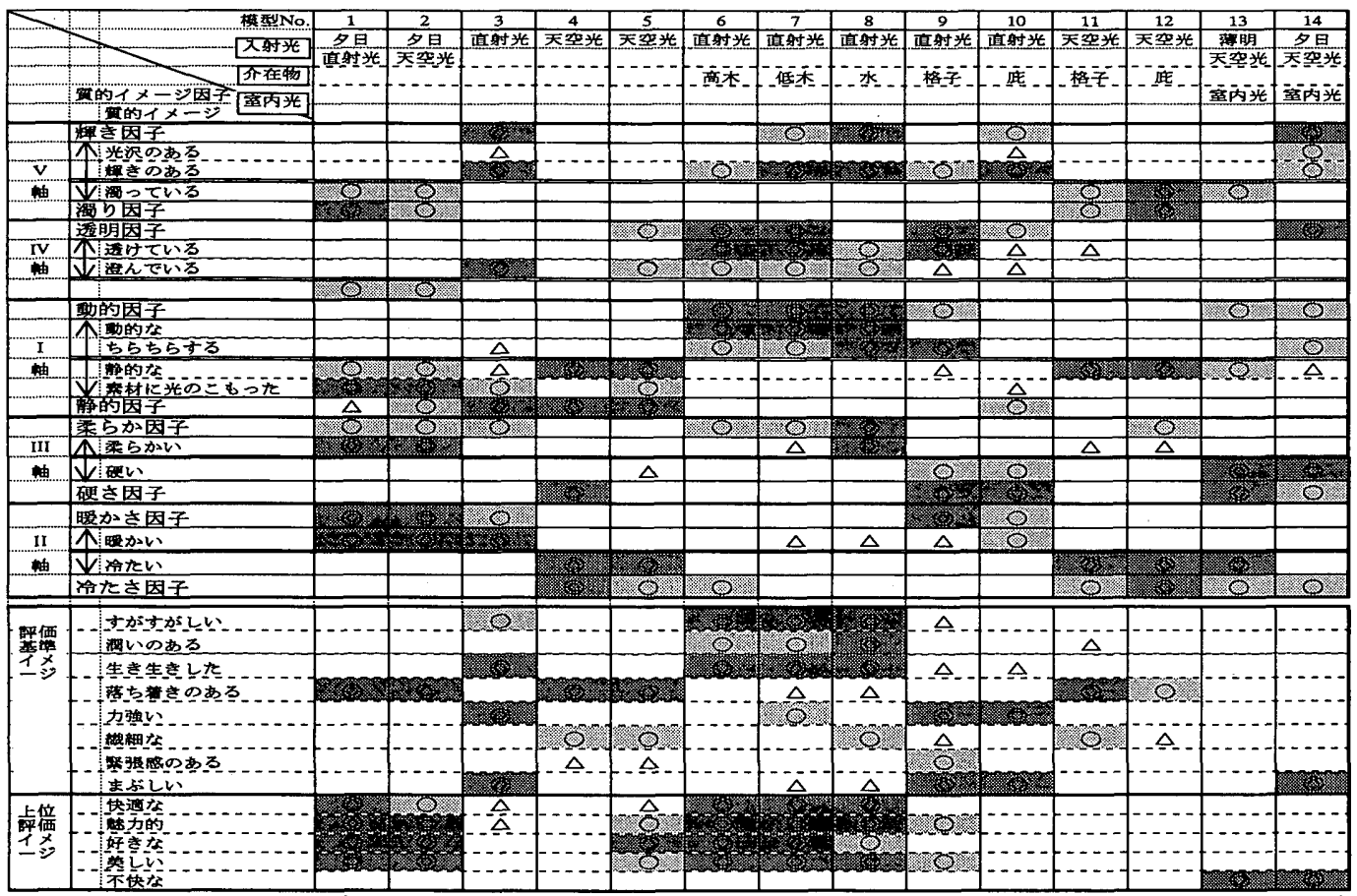

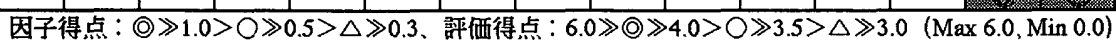

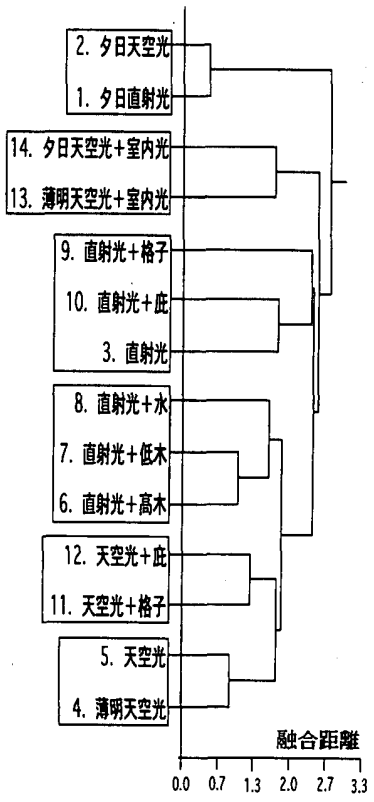

図 3 クラスター分類結果 
力といった快・魅力評価と強い結びつきがあった。次に落ち着きの ある，緎細なが快・魅力評価と結びつきがあった。緊張感のある， 力強い，まぶしいは快・魅力評価との結びつきはなかった。

(2) 質的イメージと評価イメージとの結びつき

快・魅力評価とつながりの高かった, 質的イメージ因子と評価イ メージとの結びつきを整理すると次のようになった（表 4-4))。

I 軸：動的因子は，生き生きしたと強く結びつき，また程度は低 いが,すがすがしい，潤いとも結びつき，評価されていた。一方， 静的因子は，落ち着きと結びつき評価されていた。II軸：暖かさ因 子は，程度は低いが，生き生きした，繊細なと結びつき評価されて いた。III軸：柔らかさ因子は，落ち着きと結びつき評価されていた。 IV軸：透明因子は，すがすがしいと強く結びつき，また生き生きし た，潤いとも結びつきながら評価されていた。また程度は低いが緎 細なとも結びつきがあった。V軸：輝き因子は，程度は低いが，す がすがしい，生き生きしたと結びついていた。一方，濁り因子は落 ち着き，繊細と結びついていた。

以上をまとめ，質的イメージと評価イメージとの結びつきを示す 模式図を図 2 に記す。

\section{5 、イメージ傾向の擎理}

（1）イメージ傾向把握の基礎資料（表 5 ）

どんな透過光障子面が，どんなイメージを与えるかの傾向把握の 基礎資料として，14透過光面の質的イメージ因子の因子得点および 質的イメージ，評価イメージの評価得点を整理した表を作成した。

（2）因子得点による透過光障子面のクラスタ一分類

9 因子の因子得点によってクラスター分類（最短距離法, カテゴ リー数：3）を行い, 透過光障子面が与えるイメージの差異によっ て14の透過光障子面を総合的に分類した。

その結果を図 3 に示す。これらを融合距離 2.0 付近でみると，14透 過光障子面は, (1)夕日のグループ, (2)室内光の有るグループ, (3)直 射光及び直射光によりはっきりした影の写り込みがあるグループ， (4)直射光と水, 樹木等によりまばらな影の写り込みがあるグループ, (5)天空光と庇等によりぼんやりした写り込みのあるグループ，(6)天

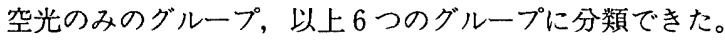

\section{6.イターージを与える要因の擎理}

\section{1 カテゴリー分類}

透過光障子面が与えるイメージ傾向の結果およびサンプル写真の 観察より，質的イメージの要因になると思われる項目を検討し，(1) 平均輝度, (2)色などの 6 項目を要因項目として設定した。そしてそ れぞれの要因項目下で，イメージに差異を与えるであろうレベルで 分類することを心がけながら，その具体内容を分類した。そして14 の透過光障子面のカテゴリー分類を行った。表 6 の左欄。

(1) 平均輝度 : (1) (5)の 5 段階 $\left(13 \sim 71 \mathrm{~cd} / \mathrm{m}^{2}\right)$

（2）輝度分布：(1)一様 (2)まばら (3)幾何学的 (4)二分 (5)中央

（3）色：(1)黄, (2)赤, (3)白·灰色, (4)青

（4）はっきりした影の有無：(1)なし (2)有

（5）ほんやりした影の有無：(1)なし (2)有

(6) 写り込み要素の有無：(1)なし (2)有

（7） 室内光の有無：(1)なし (2)有
尚, 輝度の分布については, 実験で用いたスライド写真のグレー 階調 (256階調) の写真画像を元に, 主要な部分の輝度断面図を作成 し，それらを参考にしながら分類した。図4 に代表例を記す。

\section{2 質的イメージを与える要因の数量化 I 額分析}

ここでは設計資料に役立てやすいようにという意図より，9つの 因子に抽象する前の13の質的イメージの評定值を外的基準とし，数 量化 I 頑分析を行った。としてその結果を 9 つの因子別に整理した。 このことによって全体の傾向を把握しつつ, 具体的なイメージと要 因の関係が示せると考えた。

数量化 I 類分析は, 各イメージごとに要因になるであろう要因項 目を予想して，それらを説明変数にして分析を行い，その結果の偏 相関係数, 決定係数の值が 1 に近いものになるまで, 要因項目を加 えたり減らしたりしながら，分析を数度にわたり行った。

以上の手順で行った13の質的イメージの数量化 I 数分析結果を表 6 の右欄に示す。空欄以外の部分が，そのイメージに对し説明変数 として扱った要因項目である。そして各イメージ毎に, 偏相関係数, 決定係数, 要因レンジウエイト, 規準化カテゴリーウエイト分布図 等の分析結果をまとめた表を作成した。またイメージの感じる度合 いが高い順に透過光障子面およびそのカテゴリー分類結果を並べた 表を作成した。そしてそれらより，因子別に質的イメージを与える 要因を考察した。

\section{3 イメージを与える要因のまとめ}

ここでは, 以上の考察より傾向が顕著に認められかつ妥当と判断 したものについて, 要因項目別にどんな要因項目下の具体内容がど のイメージの要因になるかを記す。尚，同じ因子軸中の対概念のイ メージでほほほ逆の傾向がみられたものについてはわかりやすさの 為, 片方のイメージについてのみ記す。表 6 中にハッチングをし記 号化したものが傾向が認められたものである。また，因子全体の傾 向ではなく，因子内の具体的な質的イメージとの相関がみられたも のについては，文中に「」にて記す。

(1) 平均輝度

ほとんどの質的イメージに影響を与える要因項目であったが，顕 著な傾向のでないイメージも多かった。こはスライドを用いた為， 低い輝度範囲でかつ輝度差が小さい範囲に対する相対評伍であるこ とが原因と思われる。顕著な傾向が認められたものを次に記す：

輝度が高いほど，輝き因子中の「輝き」が高まることが確認でき た。輝度が高すぎず低すぎない，中位が要因となっていたイメージ は，柔らかさ因子，暖かさ因子，静的因子中の「素材に光がこもっ た」であった。

(2) 輝度の分布

輝度の分布は動的 $\Leftrightarrow$ 静的因子の要因となっていた：

一様な分布 (介在物なし) は，静的因子中の「静的」の要因となっ ていた。幾何学的な分布（格子）は, 静的因子中の「静的」および 動的因子中の「ちらちらする」の要因となっていた。透過光面を光 と影の部分に二分する輝度分布（庇）は, 静的因子中の「静的」の 要因となっていた。まばらな輝度の分布（樹木や水面反射）は, 動 的因子中の「動的な」の要因となっていた。中央が明るい分布（室 内光）は，動的因子中の「ちらちらする」の要因となっていた。 (3) 色 色は多くの質的イメージに影響を与えていた： 


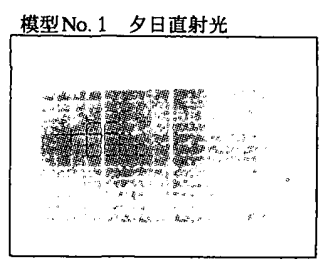

模型No. 4 薄明天空光
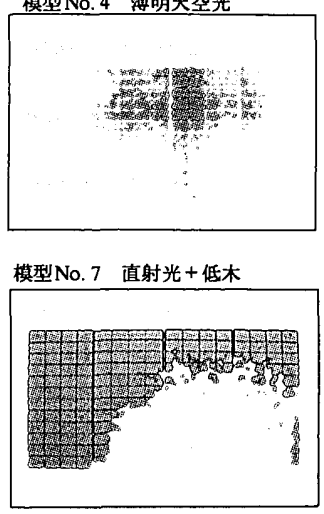

模型 No. 11 天空光 + 格子

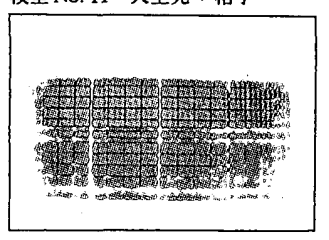

模型No. 13 骦明天空光+室内光

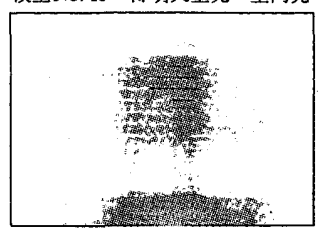

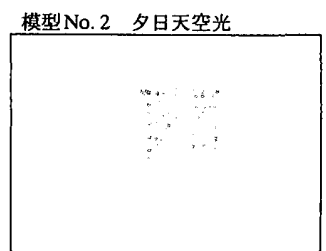
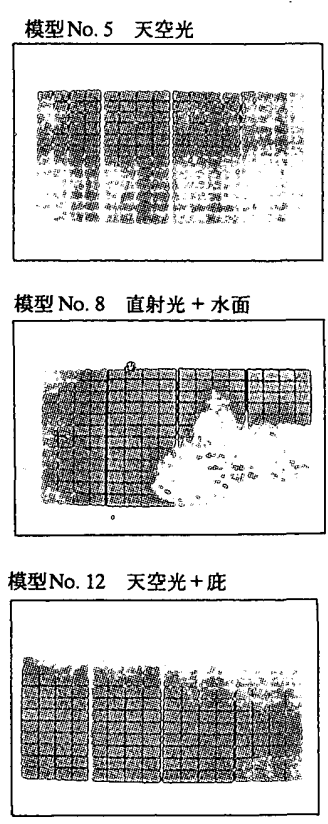

模型No. 3 直射光
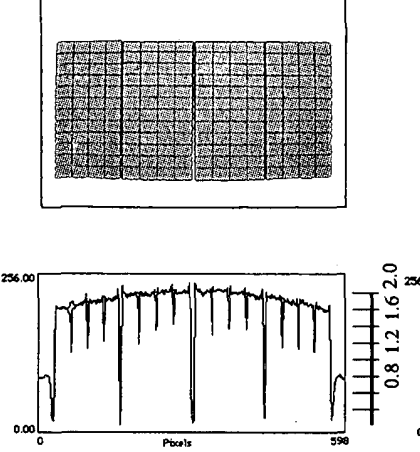

(1) 一様タイプ
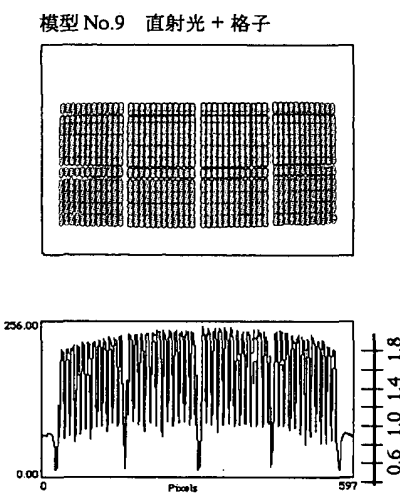

（3）幾何学的タイプ

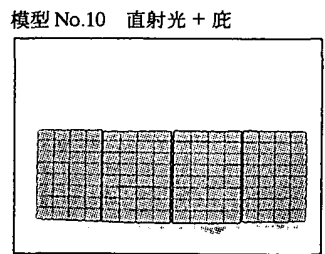

(5) 二分タイプ
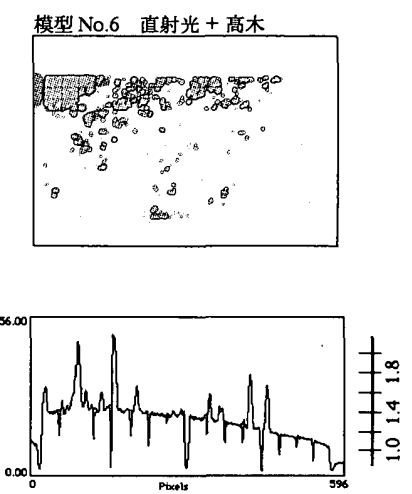

(2) まばらタイプ

模型 No.14 多日天空光 + 室内光
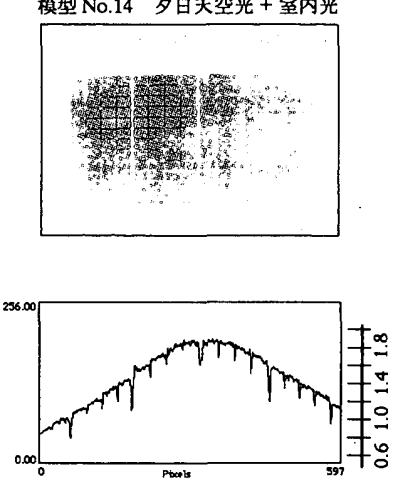

（5）中央タイプ

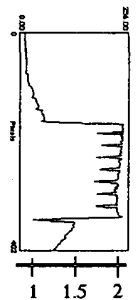

図 4 実験で扱った透過光障子面の写真及び輝度分布タイプの代表例の輝度断面図（軸 $\log \mathrm{L} ： \mathrm{~cd} / \mathrm{m}^{2}$ ）

表 6 透過光障子面の質的イメージを与える要因の結果まとめ表

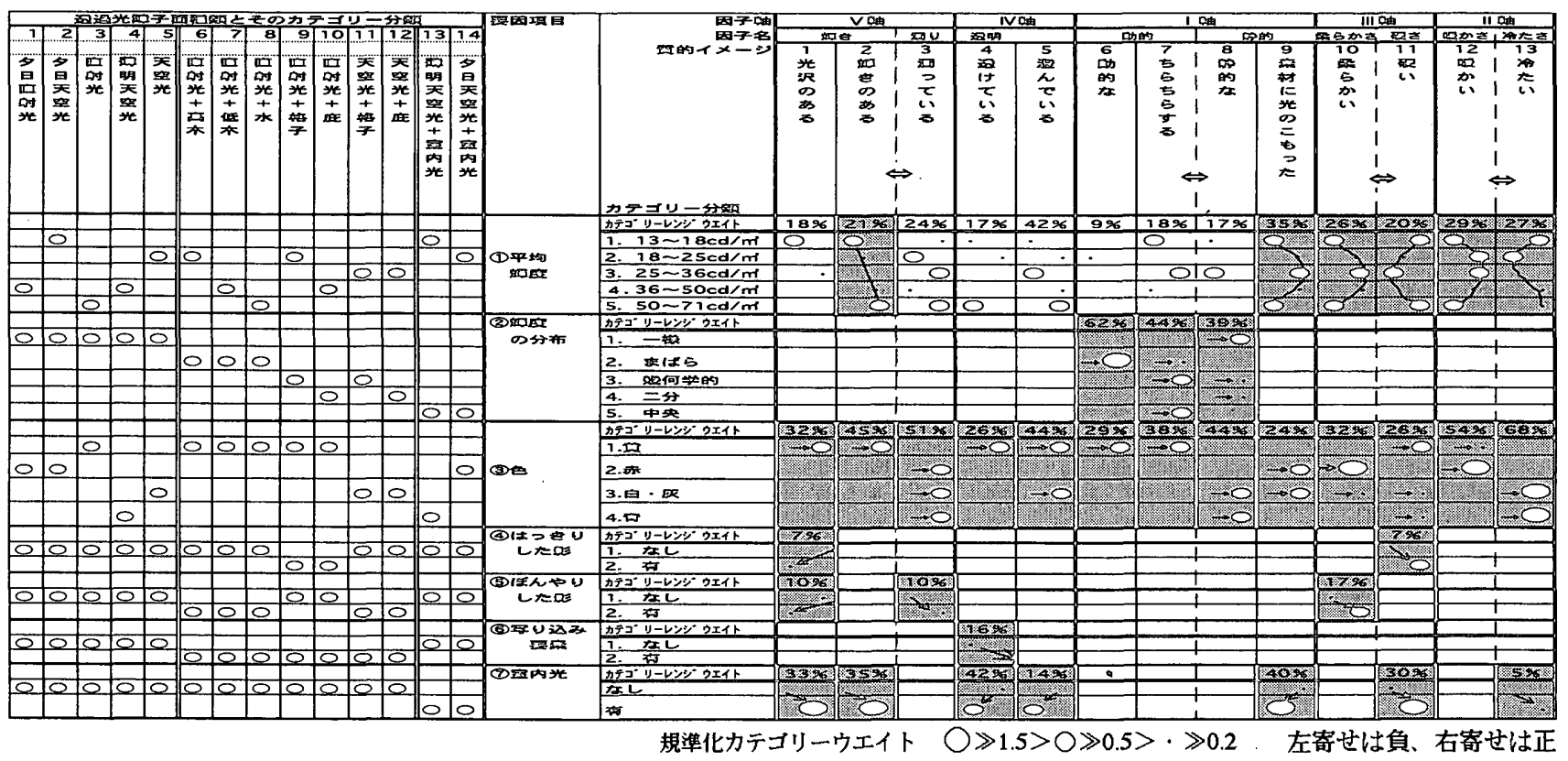


黄（直射光）は，輝き因子，透明因子，動的因子，硬さ因子の要 因になっていた。赤（夕日）は, 柔らかさ因子, 暖かさ因子の強い 要因に，また濁り因子，静的因子中の「素材に光がこもった」の要 因にもなっていた。白・灰（天空光）は，冷たさ因子の強い要因に， また濁り因子，透明因子中の「澄んでいる」，静的因子の要因となっ ていた。青（薄明天空光）は，冷たさ因子の強い要因に，また濁り 因子, 静的因子中の「静的」の要因となっていた。

(4)はっきりした影

はっきりした影が有ることが（值射光と格子・庇の組み合わせな ど), 硬さ因子の要因になっていた。一方程度は低いが，はっきりし た影が有ることが，輝き因子中の「光沢」を減じさせる要因になっ ていた。

（5）ぼんやりした影

ぼんやりした影が有ることが（天空光と格子，水面反射等の組み 合わせ), 柔らかさ因子の要因に, また程度は低いが濁り因子の要因 になっていた。一方，ぼんやりした影が有ると，輝き因子中の「光 沢がある」を減じる要因になっていた。

（6）介在物の写り込み

介在物の写り込みが有ることが, 程度は低いが, 透明因子中の「透 けた」の要因になっていた。

(7) 室内光

室内光があることが, 硬さ因子の強い要因に，また輝き因子の要 因になっていた。一方, 室内光が有ると, 透明因子, 静的因子中の 「素材に光がこもった」を強く減じる要因になっていた。

\section{7.まとめ}

入射光と介在物の異なる透過光障子面に对する評価実験より, 次 の結果を得た。

(1)透過光障子面の質的なイメージを9つの因子に代表させた。そ してそれらと評価イメージとの結びつきを捉えた。(2)どんな入射光 と介在物の組み合わせによる透過光障子面が，どんな質的イメージ を与えるかの傾向を捉えた。(3)質的イメージの要因を室内光による 影響も捉えた上で，入射光や介在物の組み合わせによって障子面に 生じる輝度の分布, 影のでき方, 写り込み要素の有無などの光現象 に求め,イメージと要因の関係を整理した。

既往研究では, 介在物や入射光種類が透過光面の質的イメージに 与える影響を捉えたものはないが, 本研究の結果は, 障子面の向い た方位や外部の庭の状況などを考慮した障子面設計に役立つと考之 る。

尚, 本研究結果はスライドによる評価実験のため, 平均輝度 16 ～71 $\mathrm{cd} / \mathrm{m}^{2}$ の範囲における相対評価の結果であり, 輝度の絶対值等につ いては別の実験を行う必要がある。

注

1）本稿は, 小泉 隆「建築空間に取り込まれた太陽光が与える空間イメージ と透過光面イメージの構造」(東京理科大学博士論文 (工学), 1999年) の 一章を構成するものである。

2）北浦かほる「透かしにおける2つの視知営タイプ」『日本建築学会計画系
論文集』，第470号，9504

3）岡本知子, 奥田宗幸「透かしとしてのパンチングメタルの視敩効果につい て」『日本建築学会大会学術梗概集』9508, No. 5402

4）石田美和，中村 仁他「ブラインドの種類による視覚的快適性の検討」同， 8510 , No. 5167

5）小泉 隆，山田高広，鈴木信宏「入射光の異なる実物大模型実験による透 過光面のイメージとその評価の傾向』『日本建筑学会計画系論文集?! 第491 号, 9701

6）小泉 隆，藤井俊洋，鈴木信宏「入射光の性犋からみた落ち弟きをもたら 寸透過光障子面のイメージと連結感及びその作り出し手法」, 同, 第457号, 9403

7）来らかい，暖かいといった透過光面の質的イメージは, 透過光面の物的要 素の種類や物理量との直接的な因果関保が捉えやすい感喾豆とししてのイ メージとして扱っている。一方，透過光面に対する評価は，染間の用途や 被験者の経験·気分等によって左右される可能性があり，その厳密な因果 関係は人間側の要因にまで踏み込まないと捉えられないと考える。そこ で, 質的イメージと評価イメージを別々に扱うことにし，質的イメージと 要因との因果関係を捉之た上で,それら質的イメージが今回の被験者や実 験室の条件においてどんな評価イメージと結びついているかの傾向を捉 えることにした。この方法により，空間の用途などがかわったときにでも 応用しやすい基整资料になると考之た。

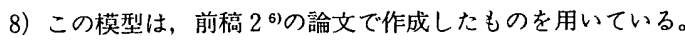

9）東京理科大学 (東京都新宿区神楽坂1-3) 7 号館屋上において (9 階建て), 各入射光種類に対して適した天候・筀の状態と判断した時候に模型のスラ イド掓影を行った。天空光は公天時，夕日は空の色が赤みを带びた状態の 時，薄明は太陽が沈む頃の空の色が青紫色の状態の時，直射光は（夕日直 射光も)太陽が直視できる時に，その光が直接障子面に届くょう障子面を その方向に向け掓影した。

10）人間の静視野に関してはいくつか説があるが, 建築を対象とした場合の静 視野の視界としては，経験説的にまた応用のしやすさより，60度の頂角を 有するコーンが, 芦原義信をはじめ多くの研究で採用されている。本研究 ではその視角 60 度のコーンに近い長辺画角 54 度である $35 \mathrm{~mm}$ レンズを用 いることにした。芦原義信『外部空間の設計」(讋国社，1975）p.52

11）障子面の平均輝度高さの算出は, 実験で用いた透過光障子面スライドを映 写した状態で, 数力所ずつスポット輝度測定を行い，それらに対応する写 真画像上のグレ一值 (256階調) を出し, 各々のスライドに対して, 直線 回帰式を算出した。そして障子面部分のグレ一值の平均值を算出し，それ を回州式に代入し障子面の平均輝度とした。スライド機材は, YOKOGAWA-VIP300(横河コンプレジョン㮫映写ランプ: クセノン $250 \mathrm{~W}$, 中心 照度：1.800) である。

12）因子分析のデータの扱いた関しては, 個人差の影響を考慮するため個人別 デー夕を基礎データとするべきとの指摘(3)もあるように，放密には個人 データを原データとして因子分析を行うべきであるが, 本研究では個人垟 が出にくいと想定した質的なイメージに对して因子分析を行っているこ と7)、イメージを mono-polor な尺度を用いている為 bi-poloa な尺度の ように個人差によって反对の評定に分かれた場合にその中立的な評価結 果にはならないことを踏まえ, 個人データのばらつきが比較的少ないこと を確認した上で,データ分析の簡略化上, 全被験者の平均儲を用い因子分 析を行うことにした。

13）讃井純一郎「空間の評侹基準をとらえる 居間の評価構造」『建築・都市 計画のための空間学』（井上書院，1990）pp.52-64

14）通常は, 対概念による 5 因子軸と命名するのが一般的だが, 本研究では, 全体的な傾向をみるための因子得点による結果と具体的な13の質的 メージの評定值の結果を同時に表現することが多いことを踏まえ，因子と 尺度の区別を付けるため，5軸 9 因子として表記することにした。尚, 既 に発表した小泉, 山田, 鈴木「入射光の異なる実物大模型実験による透過 光面のイメージとその評価の傾向」らにおいてもそのような表記方法を用 いたが,その関連研究としても同様の表記法をとることが望ましいと考え た。

（1999年11月 9 日原稿受理，2000年 5 月16日採用決定） 